Pastoral Epistles, I Clement, Ignatius, Polycarp, 2 Clement, and Justin to citations and allusions in Paul. He finds similar patterns of usage. Especially helpful are the 'negative examples' he investigates, the Didache and the Epistle of Barnabas, in which he finds a dissimilar use of Scripture. Lincicum is appropriately cautious in drawing conclusions but suggests that 'one of Paul's earliest literary influences was as a hermeneutical teacher: on his way to an ascending material authority himself, he was first sought for the entrance he provided to a greater authority: the Scriptures of Israel' (p. i69).

The uneven quality of the essays limits the volume's overall value. Some of the essays appear to be repackaging of earlier work. Yet the methodological reflections and detailed textual analyses in the volume should repay the reader who is interested in Pauline reception. At the least this volume demonstrates again that the early reception of Paul remains a fascinating and important subject of study. There are no indexes.

doi: I O. I093/jts/flso57

Advance Access publication I9 March 2012
Alexander N. Kirk Keble College, Oxford alexnkirk@gmail.com

\title{
Fesus the Light of the World. The Oxford Handbook of the Reception History of the Bible. Edited by Michael Lieb, Emma Mason, Jonathan Roberts, and Christopher Rowland. Pp. xv +725 . Oxford: Oxford University Press, 20 I I. ISBN 978 ○ I 9920454 o. $£ 85$.
}

Reception history is in vogue. Up to now, nearly all that is available is monographs, commentaries like the German series Evangelisch-Katholischer Kommentar and the British series Blackwell Bible Commentaries, and collective volumes with selected studies of the Bible. The project of a 'handbook' of the reception history of the Bible is ambitious. It requires interdisciplinary cooperation, witnessed by its editorial team, consisting of three scholars of English literature (Michael Lieb, Emma Mason, and Jonathan Roberts) and an exegete (Christopher Rowland). The result is physically impressive: a large volume containing 44 articles written by authors from seven countries. There are three different types of articles: on biblical books (Pt. I, nos. I-I2), on specific themes or persons referring to the whole Bible, such as 'Dante and the Bible' (Pt. II, nos. I3-24),

(C) The Author 2012. Published by Oxford University Press. All rights reserved.

For Permissions, please email: journals.permissions@oup.com 
and on specific topics and texts, such as 'Post Holocaust Jewish Interpretations of Job' (Pt. II, nos. 25-43). A programmatic introduction by Jonathan Roberts opens the volume; an equally programmatic article by Valentine Cunningham, 'Bible Reading and/after Theory' (no. 44), closes it.

Naturally it is impossible for one reviewer properly to appreciate all the articles and the whole volume. After having read most, I restrict myself to comments on the concept of the handbook and to some articles in the three different sections.

In his introduction (pp. I-8) Jonathan Roberts pays tribute to Hans Georg Gadamer, in whose philosophical hermeneutics reception history 'is grounded'. However Gadamer, whose interest is 'the historically effected consciousness', would probably protest: his interest was not the the development of a new ancillary discipline called 'history of effects' or 'reception history' (Truth and Method, English trans. I989, p. 300 f.). Roberts also pays tribute to my commentary on Matthew and its concept of 'Wirkungsgeschichte'. In contrast to my concept, the Handbook should be broadminded. It should not try to separate 'valid interpretations from false ones' and avoid every kind of foundationalism (p. 5). It should include 'highly diverse responses to the Bible' from different backgrounds, also 'from Islamic, Hindu, Gnostic and agnostic backgrounds' (p. 6). I am astonished to be ranked among the foundationalists: Roberts evidently did not see that the task of a commentary on a biblical book is not the same as that of a handbook. I naturally agree with him that a handbook is a descriptive genre of scholarly literature, which should include all kinds of receptions of the biblical texts without judging or assessing them. But I think it should describe and perhaps classify them, and that means to make clear whether the Bible is e.g. 'interpreted', 'used', 'performed', 'applied', etc. In this respect the whole handbook looks to me rather like a collection of essays not only 'after Theory' (p. 649), but without theory.

The first part of the handbook contains articles on the reception history of biblical books. Genesis, Job, Psalms, Isaiah, Ezekiel, Daniel, Judges, the Gospel of John, Romans, I Corinthians, Galatians, and Revelation were selected. The task for the authors was extremely difficult, since in most cases and epochs it is not the biblical books that formed the reception history, but single stories, verses, motives, persons, ideas, etc. For example: in the case of the Gospel of Matthew not the reception history of the book itself, but the reception history e.g. of the passion of Jesus, of the parable of the tares, or of the command 
to love one's enemies could be written. Moreover, how can one write an article about the reception history of the Gospel of Matthew in fifteen pages? There is no article about Matthew in the handbook. The reason is that, when asked to write one, I did not know how to do it, found no help, and finally gave it up. Thus I was very interested to see how other authors solved the task. Reading the articles, I was rather disappointed: most of the authors wrote a simple introduction to the main literary, historical, and theological problems of their book, but nothing or almost nothing about its reception history. However, there are some noteworthy exceptions: I want to commend Paul M. Joyces's article about Ezekiel, an excellent survey of its reception history from 4 Maccabees to Erich von Däniken. Excellent too is David M. Gunn's article on the book of Judges: he concentrates on the reception of the last two chapters of this book in conflict situations such as the English Civil War. Equally excellent is John Riches's article on Galatians, emphasizing not only some important effects of this powerful epistle, but also its ambiguity.

The articles in Part II have a different character: most have a clear topic and accordingly a clear profile. The topic is very broad in the case of the general articles nos. I3-24. Here the task was to select and exemplify. The topic is normally very clear in the case of the specific case studies in articles nos. 2543. The main question for a reviewer is: how were the themes of the case studies selected? In many cases the choice is evident: sometimes focal points of history and church history, where the influence of the Bible was decisive (examples: 'Karl Barth on Romans', 'Augustine and Pelagius on the Epistle to the Romans', 'Luther on Galatians', 'Exodus in Latin America'). In other cases the selection seems to have been more casual and often has a predomominantly British or North American readership in mind (examples: 'George Frederic Handel and The Messiah'; 'Sodomy and Gendered Love: Reading Genesis I9 in the Anglican Communion'; 'Samuel Wilberforce, Thomas Huxley, and Genesis'; 'Ruskin, the Bible, and the Death of Rose de La Touche'). Generally I have the impression that articles about the reception of the Bible in theology and in literary texts are somewhat overrepresented, those in visual arts, music, political actions, war- and peacemaking are somewhat underrepresented, and those about the reception of the Bible in legal texts are almost absent in the handbook.

Naturally the selection of 'cases' for case studies is always casual. But 'casual' does not mean 'illegitimate'. This is demonstrated by the fact that sometimes articles with a 'casual' topic 
are extremely fascinating and in many respects exemplary, while general articles and articles on a topic which seems to be a 'must' in a handbook of the reception history of the Bible can be boring, since they repeat what is already well known. Among the fascinating and excellent articles were-for me-Atsuhiro Asano on 'Uchimura and the Bible in Japan', Ismo Dunderberg on 'Gnostic Interpretations of Genesis', Jo Carruther on 'Esther and Hitler: A Second Triumphant Purim', Isabel Wollaston on 'Post Holocaust Jewish Interpretations of Job', and Gordon Allan about 'Joanna Southcott: Enacting the Woman Clothed with the Sun'. Only in rare cases did I find an article superfluous, e.g. the article about Dan Brown's Da Vinci Code-I hope that in 20 years no one will discuss this strange literary product of our days-or the article about Ezekiel I and the Nation of Islam, because Ezekiel I plays only a very minor and indirect role in the Islamic sect 'Nation of Islam'.

Facit: the 'Oxford Handbook of the Reception History of the Bible' is a rich collection of different and often very valuable materials on the reception history of the Bible. Among the articles some are real treasures, while others are not. Whether the book is really a handbook, or rather an anthology of different receptions of the Bible without a sufficiently clear editorial concept remains an open question.

doi: I0. I093/jts/flso 58

ULRICH LUZ

University of Bern ulrich.luz@theol.unibe.ch

The Resurrection of the Messiah. By Christopher Bryan. Pp. $x+432$. New York and Oxford: Oxford University Press, 20II. ISBN 978 ○ I9 975209 6. $£ 27.50$.

Christopher Bryan is an Emeritus Professor of New Testament in the United States and editor of the respected Sewanee Theological Review. In this book he reviews the biblical evidence for the proposition that Jesus physically rose from the dead. The main part consists of a running commentary on the crucial texts-I Corinthians I $5_{5}$ and the narratives in the four gospels and Acts-with all technical questions relegated to endnotes, which, with additional essays and a 30-page bibliography, take up half the volume. Two introductory chapters survey beliefs in the afterlife in the Jewish and Greco-Roman worlds. A relatively

(C) The Author 2012. Published by Oxford University Press. All rights reserved.

ForPermissions, please email: journals.permissions@oup.com 